CENTRE POUR LA RECHERCHE ECONOMIQUE ET SES APPLICATIONS

\title{
Imports and TFP at the Firm Level: The Role of Absorptive Capacity
}

\author{
Patricia Augier ${ }^{(1)}$, Olivier Cadot ${ }^{(2)}$, Marion Dovis ${ }^{(3)}$
}

Version février 2009

Docweb no 0903

Patricia Augier ${ }^{(1)}$ : DEFI, Univ. Aix-Marseille II 
Title : Imports and TFP at the Firm Level: The Role of Absorptive Capacity Author(s) : Patricia Augier, Olivier Cadot, Marion Dovis

Abstract : This paper estimates the effect of the decision to import intermediate goods and capital equipment on Total Factor Productivity (TFP) at the firm level on a panel of Spanish firms covering the period between 1991 and 2002. We use two alternative approaches. In the first, we estimate TFP using the Olley-Pakes semi-parametric method and apply a diff-indiff estimator with a control group constructed by propensity-score matching. In the second, direct method, we estimate TFP with imported inputs as a state variable in one stage. Both approaches show that the effect of a firm's decision to source intermediates and capital equipment abroad on its TFP depends critically on its capacity to absorb technology, measured by the proportion of skilled labor. This provides indirect evidence that imported capital equipment may embody new or different technologies that require adaptation at which some firms are better than others. If skilled labor proxies for adaptability, it is how firms adapt their production processes to the foreign inputs that seems to determine whether or not they benefit from them.

Keywords : PRODUCTIVITY, TFP, IMPORT, OLLEY-PAKES, ABSORPTIVE CAPACITY JEL classification : F2, O1, O2 


\section{Introduction}

The notion that international trade acts as a vehicle for productivity-enhancing technology diffusion has been a subject of intense scrutiny in recent years. Seminal contributions include Coe and Helpman (1995) paper, Xu and Wang (1999) and Eaton and Kortum (2001, 2002), who showed that international trade (in capital goods in the case of Xu \& Wang and Eaton \& Kortum 2001) spreads technology, with a traceable effect on productivity. Lumengo-Neso et al. (2001) showed that this technology diffusion could even go through indirect trade links ( $A$ gets $C$ s technology by trading with $B$ which trades with $C$ ). Acharya and Keller (2007) confirmed these findings but showed that the linkage between trade and productivity was largely heterogeneous across countries and sectors. These findings were suggestive of a potential causal chain from trade to technology diffusion to productivity growth.

However, as long as the unit of observation was defined at the aggregate level, the channels through which foreign technology, mediated by international trade, would translate into domestic productivity growth remained a black box. Understanding these channels would require firm-level analysis. At the firm level, there can be three possible linkages between trade and productivity, one "vertical" and two "horizontal". First, better access to imported intermediates can raise productivity because either (ia) foreign intermediates are of better quality, or (ib) simply through the production equivalent of a "love-of-variety" argument (Ethier 1982). Second, foreign competition in the final-good market can whip up the productivity of domestic producers. Third, foreign competition in the final-good market can also lead to the exit of the least productive domestic firms, as in Melitz (2003). Verifiying empirically the existence and magnitude of these channels requires firm-level analysis.

With better access to micro data, the empirical literature naturally turned to firmlevel analysis. Two strands of papers can be distinguished in this rapidly growing literature. The first looks at the overall impact of imports on TFP without disentangling vertical linkages from horizontal ones. ${ }^{1}$ In this strand, Djankov and Hoekman (2000), Bottasso and Sembenelli (2001), Halpern and Korosi (2001), Pavnick (2002), Mündler (2004), Schor (2004), and Fernandes (2007) found a

\footnotetext{
${ }^{1}$ Exportations at firm level being easier to obtain, a long-standing literature, reviewed in Wagner (2007), has explored the link between export status and productivity and found support for the self-selection hypothesis (according to which only the most productive firms can export, a direct implication of the existence of fixed export costs in Melitz's model).
} 
positive overall impact of imports on TFP. In the second strand, by contrast, vertical linkages are distinguished from horizontal ones. This strand, which includes Halpern, Koren and Szeidl (2005), Amiti and Konings (2007), Kasahara and Rodrigue (2008), Lööf and Andersson (2008), and Vogel and Wagner (2008), found widely varying effects of imports on productivity. For instance, on the basis of a panel of large Hungarian exporting firms, Halpern et al. found that a 10 percentage point increase in the share of imports raised firm productivity by $1.8 \%$ with GMM but had no impact with a fixed-effect estimator. Amity and Konings found that a 10 percentage points reduction in input tariffs raised the TFP of importing firms by $12 \%$. In the Chilean case, Kasahara \& Rodrigue found that importing intermediates raised TFP by anything between $2.6 \%$ and $22 \%$, depending on the estimator. Vogel and Wagner found no evidence of import status affecting labor productivity on the basis of German data; by contrast, Lööf and Andersson found a positive impact on the basis of Swedish data. Moreover, they found that imports from industrial countries had a stronger effect, giving support to the Coe-Helpman hypothesis.

By and large, the balance of findings so far is in favor of a positive overall effect, in line with the discussion above. But the findings' heterogeneity is disturbing, and there is lingering uncertainty about which channel matters most. This paper starts from the idea that the effect of trade on productivity depends not only on firm involvement in trade, but also on other firm characteristics. Empirical studies find that firms using imported intermediates are fairly different (across a broad range of individual characteristics) from firms that don't. ${ }^{2}$ TFP comparisons that do not properly account for firm heterogeneity across groups may end up comparing apples and oranges. In addition, most of the empirical literature has focused on the effect of importing intermediates. But firms may also import capital equipment, and foreign capital equipment may embody new or different technologies. How the decision to import affects TFP may then depend not just on where firms import their inputs from (as in Lööf and Andersson) but also on the firms' ability to "absorb" the technology embodied in foreign capital equipment.

We overcome the heterogeneity problem with a combination of approaches. The first one is in two stages. In stage 1 , we estimate TFP à la Olley-Pakes (OP) using firm fixed effects in order to control for unobserved time-invariant firm characteristics. In

\footnotetext{
${ }^{2}$ For instance, Kasahara and Lapham (2008), Andersson et al. (2008), and Muuls and Pisu (2007) show that firms that import and export (two-way traders) tend to be more productive than those that only import or only export.
} 
stage 2, we regress TFP on the firm's importing status. Stage 2 combines a differencein-differences estimator with propensity-score matching in order to control for heterogeneity between the treatment and control groups. As argued by Blundell and Costa Dias (2000) this combination is the most reliable way of estimating treatment effects and has so far been used only by Vogel and Wagner (2008) in the TFP-andimports context 3 .

The second approach is direct (one stage), and controls for possible correlation between importing status and unobserved productivity shocks by including the share of imported intermediates directly in the OP-estimated production function. In addition to a stronger control for endogeneity of importing status, this approach has the advantage of using all the information contained in importing decisions (not just status, but also share).

We are able to control for the absorptive capacity of firms thanks to a particularly rich panel of Spanish firms 4 (covering the period between 1991 and 2002). In addition to data on purchases of foreign intermediates and capital equipment, it includes the proportion of skilled labor as well as R\&D expenditure, which we use to proxy absorptive capacity. Our identification strategy consists in interacting these firm characteristics with importing status in the second-stage regressions (first approach) or, alternatively, in estimating the impact of the share of imports for groups of firms differentiated by skilled employment, R\&D intensity, and others characteristics. We also control, albeit imperfectly, for possible markup effects using market-share data (also in the database).

Our results are strong and telling. Without interaction with firm characteristics, the effect of importing status on TFP is only weakly identified. By contrast, once importing status is interacted with the proportion of skilled labor, the effect is very significant and robust across a variety of specifications. With the two-stage approach, we find that starting to import intermediates and capital equipment raises productivity by 9 percentage points the first and second years and by 7 percentage

\footnotetext{
3 Matching methods have been used by Girma et al. (2004), Girma et al. (2007) and De Loecker (2007) to analyze the effect of exporting status on firm-level TFP. 4 Most studies on Spanish firms (e.g. Delgado et al. 2002, Campa 2004, Fariñas and MartinMarcos 2007) have focused on the relationship between exports and productivity. Others studies, including Castellani and Zanfei (2003), Jabbour and Mucchielli (2007) and Sembenelli and Siotis (2008), looked at foreign indirect investments. Lastly, some papers examined innovations (Huergo, 2006, Diaz-Diaz, Aguiar-Diaz et De Saa-Perez, 2008, VegaJurado et al. 2008). To the best of our knowledge, no study has yet been carried out on the link between imports and productivity.
} 
points the third year for skill-intensive firms. With the direct approach, we find that a ten-percentage point increase in the share of imports in total intermediates and capital-goods purchases raises TFP by $1.9 \%$ on average for the whole sample. But this effect is larger for "skill-intensive" firms and significant only for them.

Our results lend support to the hypothesis that, over and above any contestability effect, imports raise TFP by giving access to more and possibly better inputs; the importance of absorptive capacity providing indirect support to the notion that foreign capital equipment brings in better technology. 5

The paper is organized as follows. Section 2 reviews estimation issues for our two approaches (two-step and direct). Section 3 presents the data. Sections 4 and 5 present estimation results and discuss a variety of robustness issues. Section 6 concludes.

\section{Estimation issues}

As discussed in the introduction, our first procedure goes in two stages. In the first, we obtain consistent estimates of Total Factor Productivity (TFP) at the firm level using a semi-parametric method developed by Olley and Pakes (1996, henceforth OP). The OP method provides consistent estimates in the presence of endogenous input choices and selection issues using investment as a proxy for unobservable firmspecific shocks.

In the second stage of our procedure, described in section 2.1, we apply a treatmenteffects methodology to assess the impact of import status on TFP, using propensityscore matching to construct a control group of non-importing firms with characteristics similar to those of importing firms. Our alternative, direct approach is discussed in section 2.2.

\subsection{Stage 2: TFP and import status}

The second part of our procedure consists of analyzing how a firm's decision to start importing affects its estimated TFP. This is a "treatment-effect" problem where, as in most treatment-effect problems in economics, difficulties come from the definition of 
the control group and the proper way of addressing the treatment's endogeneity. We do this by combining a difference-in-differences estimator with construction of the control group by propensity-score matching, following Rosenbaum and Rubin (1983). The diff-in-diff estimator compares the change in the TFP of importing firms when they start importing with the change in the TFP, over the same years, of similar firms that never imported. The propensity-score matching serves to identify the "similar" firms. The second stage goes, like the first, in several steps.

Step 1. We start with the definition and selection of the treatment and control groups. The treatment group is the set of firms that start importing at some $t$ in the sample period but did not do so before. Because the treatment is a voluntary decision instead of being randomly assigned, the decision to take it has to be modeled as a function of firm observables. The decision to import at $t$, conditional on not importing at $t-1$ (the treatment), is accordingly modeled as a probit on a vector $\mathbf{x}_{i t}$ of lagged firm characteristics (profit, ${ }^{6}$ estimated TFP, export status, size, capital-labor ratio, and squared productivity growth) affecting both the decision to import and the level of TFP. That is, letting

$$
\theta_{i t}=\left\{\begin{array}{cc}
1 & \text { if firm } i \text { imports inputs at } t \\
0 & \text { otherwise }
\end{array}\right.
$$

we run an equation of the type

$$
\operatorname{Pr}\left(\theta_{i t}=1 \mid \theta_{i, t-1}=0\right)=\Phi\left(\mathbf{x}_{i, t-1}, \delta_{j}\right)
$$

Where $\delta_{j}$ are industry effects. Estimation of (2) by probit on the whole sample (importing and non-importing firms) yields an estimated propensity score which, by abuse of notation, we will denote again by $\hat{p}_{i t}$.

\footnotetext{
${ }^{6}$ Lagged profits control for something like "Ashenfelter's dip", i.e. firms turning to imports at $t$ because they experienced a drop in profits at $t-1$ (the original Ashenfelter dip was the observation that individuals tend to enrol in training programs after a temporary earnings dip; ignoring the dip would bias estimates by attributing to the training program the effect of the recovery from the dip).
} 
The control group is constructed by propensity-score matching using scores estimated from (2). For each importing firm $i$, in general the matching procedure 7 selects the non-importing firms $j$ whose propensity score $\hat{p}_{j t}$ lies within a predetermined distance $\lambda$ (we take $\lambda=0.01$, which means that "matchable" firms must differ in their probability of taking the treatment by no more than $1 \%$ ). When several firms fall within this distance, weights $w_{i j}=w\left(\hat{p}_{i}, \hat{p}_{j}\right)$ are attributed to each of them. ${ }^{8}$ We use the caliper matching method, i.e. we take the non-treated firm whose propensity score falls within a pre specified radius with the treated. We also impose a "common support" constraint; that is, if no firm $j$ such that $\left|\hat{p}_{j t}-\hat{p}_{i t}\right|<\lambda$ can be found, we throw $i$ out of the sample.

The validity of the control group constructed this way is assessed on the basis of "balancing score" tests (see Smith and Todd 2005a, 2005b), whose logic is detailed in annex.

Step 2. Letting $q_{i t}$ (without the hat) denote TFP estimated in the first stage, the baseline diff-in-diff equation is

$$
q_{i t}=\boldsymbol{\alpha}_{t}+\boldsymbol{\alpha}_{\ell}+\alpha_{1} \Theta_{i t}+\boldsymbol{\alpha}^{\prime} \mathbf{x}_{i t}+\varepsilon_{i t}
$$

where $\Theta_{i t}=1$ marks the event that firm $i$ switches import status at $t$ (from $\theta_{i, t-1}=0$ to $\left.\theta_{i t}=1\right)$ :

$$
\Theta_{i t}=\left\{\begin{array}{cc}
1 & \text { if firm } i \text { switches import status at } t \\
0 & \text { otherwise }
\end{array}\right.
$$

$\mathbf{x}_{i t}$ is a vector of firm and industry characteristics, and $\boldsymbol{\alpha}_{\ell}$ is a vector of location dummies. We run several variants of (3), discussed in the course of the paper. We include lagged values of $\Theta_{i t}$ to allow for dynamic (learning) effects. One variant

\footnotetext{
7 This procedure is implemented by Stata's psmatch2 command, due to Leuven and Sianesi (2003).

8 The choice of a weighting scheme is, again, the experimenter's decision.
} 
distinguishes between one-time and repeated switchers and another one uses the interaction between the binary status and the skilled labor share.

\subsection{The direct approach}

The preceding subsection presented a two-stage methodology to evaluate the impact of starting to import on productivity. Using the OP method in the first stage took care of selection and endogeneity of input choices to unobservable shocks. Endogeneity of importing status to time-invariant unobservable firm characteristics was controlled for by fixed firm effects. We turn now to alternative, direct estimation method where the share of imports in intermediates and capital equipment purchases is directly included as a regressor in the TFP equation and treated as endogenous like investment. This amounts to assuming that firms anticipate how imports will affect their productivity. Using the share of imported intermediates and capital (rather than the binary import status), our TFP equation becomes

$$
y_{i t}=\beta_{0 i}+\beta_{2} \ell_{i t}+\beta_{3} m_{i t}+\phi\left(i_{i t}, k_{i t}, \mu_{i t-1}^{*}\right)+v_{i t}
$$

where $\mu_{i t-1}^{*}=\ln \left[(M+I)_{i t-1}^{*} /(M+I)_{i t-1}\right]$

This alternative procedure has some similarity to the one used, inter alia, by Kasahara \& Rodrigue (2008), but we modify it in order to explore the central hypothesis of this paper, namely that the effect of imports on productivity depends on the firm's absorptive capacity. In order to do so, for each firm characteristic $z_{i t}^{k}$ of interest to us (R\&D intensity, skill intensity, etc.) we define a cutoff level $z_{0}^{k}$ (we tried many for robustness) and an indicator function $\xi_{i t}^{k}$ such that

$$
\xi_{i t}^{k}= \begin{cases}1 & \text { if } z_{i t}^{k} \geq z_{0}^{k} \\ 0 & \text { otherwise }\end{cases}
$$

That is, suppose that $z_{i t}^{k}$ is the share of skilled manpower in the firm's labor force. Then $\xi_{i t}^{k}=1$ characterizes skill-intensive firms (those we presume have a high absorptive capacity for foreign technology embodied in imported inputs). Using 
characteristic $k$ to determine the "high" and "low" groups, we then have a production function (in logs) of the form

$$
y_{i t}=\beta_{0 i}+\beta_{2} \ell_{i t}+\beta_{3} m_{i t}+\phi\left(i_{i t}, k_{i t}, \mu_{i t-1}^{*} \xi_{i t}^{k}, \mu_{i t-1}^{*}\left(1-\xi_{i t}^{k}\right)\right)+v_{i t}
$$

We estimate (7) by the usual OP procedure, and repeat the estimation exercise for various groupings [some of which multiple-category generalizations of (6)], each defined by an individual characteristic $k$. If a high value of $z_{i t}^{k}$ denotes a high absorptive capacity, we hypothesize that $\beta_{4}>\beta_{5}$, with $\beta_{4}$ and $\beta_{5}$, the respective coefficients of $\mu_{i t-1}^{*} \xi_{i t}^{k}$ and $\mu_{i t-1}^{*}\left(1-\xi_{i t}^{k}\right)$.

\section{Data}

\subsection{Data sources}

Our firm data is an unbalanced panel of 3'462 firms covered by Spain's Encuesta Sobre Estrategias Empresariales (ESEE), a very detailed annual manufacturing survey covering $70 \%$ of all firms above 200 employees and $5 \%$ of firms below 200 employees between 1991 and 2002. The initial number of observations was 24'139. Our method for cleaning the data is largely inspired by Hall and Mairesse (1995). We interpolated missing data only for single unreported years (131 observations). We excluded firms never reporting any value added (322) or intermediate consumptions (12), as well as those reporting more exports than their turnover (2 observations). We also threw out the top and bottom $1 \%$ of the sample in terms of value added per employee, output per employee and capital per employee (1'071 observations). Finally we threw out observations where value added or output grew by more than $300 \%$ or dropped by more than $90 \%$ over one year, and those whose employment or capital stock grew by more than 200\% or dropped by more than 50\% (376 observations). The cleaning job reduced our sample to 2'722 firms tracked between 1991 and 2002, or 19'589 observations.

Output, capital and intermediate consumptions are all measured in millions of constant pesetas using the Instituto Nacional de Estadistica's sectoral price indices as deflators. Labor is the number of employees. The capital stock was constructed from investment data using the Perpetual Inventory Method (PIM) with the sum of 
corporate fixed assets as initial values and a rate of depreciation taken from Mas, Perez and Uriel (2003).

Data on foreign purchases does not distinguish between intermediates and capital equipment. This does not matter when using a binary classification of firms between importing and non-importing ones. We gain added precision by using actual amounts purchased, but then those must be compared to total purchases of intermediates and capital goods to be meaningful.

\subsection{Descriptive statistics}

Table 1 shows descriptive statistics for the firms in our sample, averaged over the whole sample period. Because the distinction between firms that import intermediates and firms that don't is at the core of our analysis, the table distinguishes between three categories: (i) firms that never used imported intermediates ( $28 \%$ of the sample), (ii) firms that always used imported intermediates ( $40 \%$ of the sample), and (iii) firms that switched status once or more (the remaining $32 \%$ ).

Table 1:Descriptive statistics for Spanish firms

It can be seen from TablTable 1 that there is a huge difference in the average size of importing firms relative to non-importing ones (the former are thirty-two times larger than the latter in terms of output and thirty-seven times larger in terms of capital). Because they are also 2.6 times more capital-intensive, importing firms are only fourteen times larger than non-importing ones in terms of employment. Importing firms are slightly more intensive in their use of intermediates (59\% of output value against $49 \%$ for non-importing firms), tend to export more ( $27 \%$ of their output against $3 \%$ for non-importing ones), and have R\&D ratios nine times higher. Finally, the least surprising observation is that the share of foreign capital is much higher (35\%) for importing firms than for non-importing ones (1\%), suggesting that foreign-owned firms tend to buy intermediates abroad -possibly in parent companies - more than domestically-owned ones. In all dimensions, the average characteristics of switching firms are, unsurprisingly, convex combinations of those of importing and non-importing ones.

These large differences in individual characteristics across groups defined by importing status highlight the need for a careful construction of the control group. 
Using a propensity-score matching approach ensures that we compare firms that are comparable instead of raw categories that are obviously too heterogeneous to be compared.

\section{Two-stage estimation results}

\subsection{TFP estimation}

Table 2 reports parameter estimates for industry production functions based on the OP/LP methodology described in Section 2.

Table 2: Production function parameter estimates, by industry

Figure 1 shows the evolution of estimated TFP over the sample period for our three firm types as defined by import status: always importing, never importing and switching.

Figure 1: Average TFP by import status

It can be seen that TFP curves for importers and non-importers diverge early on in the sample period, with importers having consistently higher TFP after 1993. However, no conclusion can be drawn from simple inspection of Figure 1, as TFP differences across groups can be simply composition effects. In order to assess whether these differences are "explained" by importing status, we now turn to the econometric analysis with in first the treatment effect.

\subsection{Treatment effect}

Table 3 reports balancing score tests for the TFP variable. The same tests are applied to all variables of the probit specification but not reported for brevity. In all cases, conditions for the validity of the control group are satisfied.

Table 3: Balancing score tests, TFP

Table 4 shows OLS with robust standard errors and outlier-robust ${ }^{9}$ estimation results $^{10}$ for (3) with lagged values of what we call "entry”, by which we mean

\footnotetext{
9 See Rousseeuw and Leroy (1987) or Hamilton (1991).
} 
switching from non-importing to importing status. In the first column, the treatment group is the set of all firms that start importing at least once over the sample period. In the second, the treatment group is split between two sub-groups: one is made of firms that switch from non-importing to importing status only once in the sample period ("single switchers"), and the other is made of firms that switch several times ("multiple switchers"). The idea behind this subdivision of the treatment group is as follows. When a firm starts importing intermediates or capital equipment, either it observes an improvement in its operations or it does not. In the first case, it will either keep on importing or convince its domestic suppliers to match the foreign specifications (for a discussion of this, see Blalock and Veloso 2007), in which case it will cease permanently to import. This is our first sub-group. In the second case, it will stop and retry with other foreign suppliers, incurring multiple spells. This is our second sub-group. Thus, we would expect to see an effect on TFP in the first case but not in the second: these are like two different treatments for which we have different priors.

As market shares and Herfindahl indices were insignificant and their omission did not affect results, we present the results of regressions without those variables.

\section{Table 4: Effect of import status on TFP}

It can be seen that the effect of switching to imported intermediates is insignificant in the barebones version of the equation (first column). However, when importing status is interacted with the single vs. multiple-switcher dummy, the effect of switching becomes significant for the first category. The impact effect is an 8-10\% boost in TFP (significant at 1\%), with a long-run effect (after two years) in the 13-17\% range. This is a large effect.

In order to shed more light on the mechanisms determining the impact of becoming importer, we have estimated an equation interacting import status with firm characteristics (other than single/multiple switcher). It can be seen (again in the table 4) that interacting the importing status of firms with the proportion of skilled labor changes radically the results compared to the equation's barebones version. Firms with a share of skilled labor more than $10 \%$ above the sample mean get a 
productivity gain of $9 \%$ when they start importing. The significant and large coefficient for the following years show that this productivity-enhancing effect of imports is persistent. Other interaction terms, by contrast, are insignificant.

\section{Direct estimation results}

If the decision to purchase foreign intermediates is a short-run one, it may be correlated with the unobserved idiosyncratic shock $\omega_{i t}$. If that is true, the OP approach should be applied to purchases of foreign as well as domestic inputs. In order to verify that our results are not biased by inadequate treatment of this endogeneity, we re-estimate the production function with import share as one of the regressors. Estimation results, by industry, are shown in Table 5 .

Table 5: Direct approach production function parameter estimates, by industry

The share of imported inputs has a positive and significant effect on TFP in 10 out of 14 industries, the four exceptions being leather products, wood and paper, rubber and plastics, and other non-metallic mineral products. All of these industries transform imported raw materials (leather, rubber, timber, and ores) and it is reassuring that our measure of TFP does not pick up anything for them. The highest coefficients are obtained for printing products (0.426), machinery and equipment (0.281) and office equipment and precision (0.201).

The first column of Table 6 shows results for the whole sample. We can see that a 10percentage points increase in import share raises TFP by 1.9\%. This result is close to Kasahara \& Rodrigue'results for Chile and to Vogel \& Wagner's results for Germany, although their estimation procedures are different. Getting back to absorptive capacity, the other columns in Table 6 show estimation results by groups defined on individual firm characteristics. For each characteristic $z_{i t}^{k}$, coefficients on labor $(\ell)$, capital $(k)$, and total materials are the same for "high-value" and "low-value" groups. For the coefficients on $\mu^{*}$, we interact the import share with a "high-low" dummy indicator using the seventy-fifth percentile as the switchpoint for each characteristic.

Several interesting results emerge. The first concerns the effect of the share of imports by skilled-employment group. For the « low-skill » group of firms, the coefficient is not significant. By contrast, for the "high-skill" group, the coefficient is significant and very large, indicating that a 10 percentage points increase in the share 
of imports raises TFP by 4.1\%. The effect is weaker but goes in the same direction between groups defined on R\&D intensity.

The effect of imports on TFP is also stronger for firms with a high share of foreign capital. This may be due in part to foreign-owned firms purchasing intermediates from the parent company, in which case they are likely to get technical assistance as well. The effect is also a bit stronger for firms with a high market share or a high growth in profitability, but by a small margin. The margin's smallness, incidentally, suggests that our productivity effects are not driven by differences in markups.

Finally, and surprisingly, the productivity-enhancing effect of imports appears smaller for firms that export more. Thus, our sample does not seem to confirm the complementarity between imports and exports found by other authors.

Table 6: Direct approach production function parameter estimates, by group

In total, our results suggest that firms with a substantial share of skilled manpower or foreign capital benefit more from imported inputs than others.

\section{Concluding remarks}

Whether based on a direct approach (in which foreign intermediates are included directly in the production function) or on a diff-in-diff estimator with a control group constructed by propensity-score matching, our results suggest, in accordance with the recent literature, that importing foreign intermediates and capital raises total factor productivity at the firm level, pointing a learning by importing effect.

But they also show that this effect is not the same across firms. Using a rich dataset of Spanish firms, we find that absorptive capacity, proxied by the firm's skill intensity, significantly enhances this effect. For instance, a firm with a proportion of skilled personnel above the seventy-fifth percentile stands to benefit twice more from imported intermediates and capital, in terms of TFP, than one below that cutoff.

We also find that firms with foreign capital stand to benefit more than others from importing intermediates and capital. This can be interpreted as suggesting that learning effects are important, whether through familiarity with foreign equipment or, possibly, through the presence of training programs and foreign management 
(more likely in firms with foreign capital, where the parent company may happen to be the provider of foreign equipment).

These results suggest that average correlations between TFP and various measures of exposure to international trade should be interpreted cautiously, as the benefits that exposure can bring about depend in large part on absorptive capacity, which cannot be assessed without detailed data on the firm's activities and characteristics. In terms of economic policy, our results also suggest that trade-liberalization reforms could be made more effective in terms of raising an economy's productive efficiency (putting aside allocative-efficiency issues) if accompanied by training programs or specific aids for the hiring of skilled personnel (engineers and technicians) aimed at potential importers, not just exporters (the usual target for assistance). 


\section{References}

Acharya, R.C., Keller, W., 2007. Technology Transfer through Imports. NBER Working Paper 13086.

Amiti, M., Konings, J., 2007. Trade Liberalization, Intermediate Inputs and Productivity: Evidence from Indonesia. American Economic Review 97, 5, 1611-1638.

Anderson, M., Lööf , H., Johansson, S., 2008. Productivity and international trade: Firm level evidence from a small open economy. Review of World Economics 144, 4, 774-801.

Blalock, G., Veloso, F.M., 2007. Imports, Productivity Growth and Supply Chain Learning. World Development 35, 1134-1151.

Blundell, R., Costa Dias, M., 2000. Evaluation Methods For Non-Experimental Data. Fiscal Studies 21, 427-468.

Bottasso, A., Sembenelli, A., 2001. Market Power, Productivity and the EU Single Market Program: Evidence from a Panel of Italian Firms. European Economic Review 45, 167-186.

Campa, J.M., 2004. Exchange Rates and Trade: How Important is Hysteresis in Trade? European Economic Review 48, 527-548.

Castellani, D., Zanfei, A., 2003. Technology Gaps, Absorptive Capacity and the Impact of Inward Investments on Productivity of European Firms. Economics of Innovation and New Technology 12, 6, 555-576.

Coe, D., Helpman, E., 1995. International R\&D Spillovers. European Economic Review 39, 859-887.

Dehejia, R., Wahba, S., 2002. Propensity Score Matching Methods for Non Experimental Causal Studies. Review of Economics and Statistics 84, 151-161.

Delgado, M.A., Fariñas, J.C., Ruano, S., 2002. Firm Productivity and Exports Markets: A Non Parametric Approach. Journal of International Economics 57, 397422.

De Loecker, J., 2007. Do Exporter Generate Higher Productivity? Evidence From Slovenia. Journal of International Economics 73, 69-98.

Djankov, S., Hoekman, B., 2000. Market Discipline and Corporate Efficiency: Evidence From Bulgaria. Canadian Journal of Economics 33, 190-212.

Diaz-Diaz, N.L., Aguiar-Diaz, I., De Saa-Perez, P., 2008. The Effect of Technological Knowledge Assets on Performance: The Innovative Choice in Spanish Firms. Research Policy 37, 1515-1529. 
Eaton, J., Bernard, S., Kortum, S., 2001. Trade in Capital Goods. European Economic Review 45, 5, 1195-1235.

Eaton, J., Bernard, S., Kortum, S., 2002. Technology, Geography and Trade. Econometrica 70, 5, 1741-1780.

Ethier, W., 1982. National And International Returns to Scale in the Model Theory of International Trade. American Economic Review 72, 3, 389-405.

Fariñas, J.C., Martin-Marcos, A., 2007. Exporting and Economic Performance: FirmLevel Evidence For Spanish Manufacturing. The World Economy 30, 4, 618-646.

Fernandes, A.M., 2007. Trade Policy, Trade Volumes and Plant-Level Productivity in Colombian Manufacturing Industries. Journal of International Economics 71, 52-71.

Frankel, J., Romer, D., 1999. Does Trade Cause Growth? American Economic Review 89, 379-399.

Girma, S., Greenaway, D., Kneller, R., 2004. Does Exporting Increase Productivity? A Microeconometric Analysis of Matched Firms. Review of International Economics $12,855-866$.

Girma, S., Kneller, R., Pisu, M., 2007. Do Exporters Have Anything to Learn From Foreign Multinationals? European Economic Review 51, 981-998.

Hall, B. H., Mairesse, J., 1995. Exploring The Relationship Between R\&D and Productivity In French Manufacturing Firms. Journal of Econometrics 65, 263-293.

Halpern, L., Koren, M., Szeidl, A., 2005. Imports and Productivity. CEPR DP 5139.

Halpern, L., Korosi, G., 2001. Efficiency And Market Share In The Hungarian Corporate Sector. Economics of Transition 9, 3, 559-592.

Hamilton, L.C., 1991. How Robust Is Robust Regression?. Stata Technical Bulletin 2, 21-26.

Kasahara, H., Rodrigue, J., 2008. Does The Use of Imported Intermediates Increase Productivity? Plant-Level Evidence. Journal of Development Economics 87, 106-118.

Kasahara, H., Lapham, B., 2008. Productivity and the Decision to Import and Export: Theory and Evidence. Forthcoming, Journal of International Economics.

Keller, W., 1996. Absortive Capacity: On the Creation and Acquisition of Technology in Development. Journal of Development Economics 49, 199-227.

Huergo, E., 2006. The Role of Technological Management As a Source of Innovation: Evidence From Spanish Manufacturing Firms. Research Policy 35, 1377-1388. 
Jabbour, L., Mucchielli, J.L., 2007. Technology Transfer Through Vertical Linkages: The Case of The Spanish Manufacturing Industry. Journal of Applied Economics 10, $115-116$.

Leuven, E., Sianesi, B., 2003. PSMATCH2: Stata Module to Perform Full Mahalanobis And Propensity Score Matching, Common Support, Graphing, and Covariate Imbalance Testing.

Http://Ideas.Repec.Org/C/Boc/Bocode/S432001.Html.

Lööf, H., Anderson, M., 2008. Imports, Productivity and the Origin Markets: The Role of Knowledge-Intensive Economies. The Royal Institute of Technology CESIS, Electronic WP 146.

Lumenga-Neso, O., Olarreaga, M., Schiff, M., 2001. On 'Indirect' Trade-Related R\&D Spilloversy. Mimeo, World Bank.

Mas, M., Pèrez, F., Uriel, E., 2003. Stock De Capital En España Y Su Distribucion Territorial (1964-2000). Fundacion BBVA, Bilbao, http://Www.Fbbva.Es.

Melitz, M., 2003. The Impact of Trade on Intra-Industry Reallocations and Aggregate Industry Productivity. Econometrica 71, 1695-1725.

Mündler, M., 2004. Trade, Technology, and Productivity: A Study of Brazilian Manufacturers, 1986-1998. Department of Economics, UC San Diego, University of California At San Diego, Economics Working Paper.

Muûls, M., Pisu, M., 2007. Imports And Exports at the Level of the Firm: Evidence From Belgium. LSE, Center For Economic Performance, DP 801.

Olley, S., Pakes, A., 1996. The Dynamics Of Productivity in The Telecommunications Equipment Industry. Econometrica 64, 1263-1297.

Pavcnik, N., 2002. Trade Liberalisation, Exit, and Productivity Improvements: Evidence From Chilean Plants. Review of Economic Studies 69, 245-276.

Rosenbaum, P., Rubin, D.B., 1983. The Central Role of The Propensity Score in Observational Studies For Causal Effects, Biometrika 70, 41-55.

Rosenbaum, P., Rubin, D.B., 1985. Constructing a Control Group Using a Multivariate Matched Sampling Method that Incorporates the Propensity Score. The American Statistician 39, 33-38.

Rousseeuw, P.J., Leroy, A.M., 1987. Robust Regression And Outlier Detection. New York: John Wiley \& Sons.

Schor, A., 2004. Heterogeneous Productivity Response To Tariff Reduction. Evidence From Brazilian Manufacturing Firms. Journal of Development Economics 75, 373-396. 
Sembenelli, A., Siotis, G., 2008. Foreign Direct Investment And Mark-Up Dynamics: Evidence From Spanish Firms. Journal of International Economics 76, 107-115.

Smith, J., Todd, P., 2005a. Does Matching Overcome Ladonde's Critique of Nonexperimental Estimators? Journal of Econometrics 125, 305-353.

Smith, J., Todd, P., 2005b. Rejoinder. Journal of Econometrics 125, 365-375.

Vega-Jurado, J., Gutiérrez-Gracia, P., Fernandez-De-Lucio, I., Manjarrés-Henriquez, L., 2008. The Effect of External and Internal Factors On Firms'product Innovation. Research Policy 37, 616-632.

Vogel, A., Wagner, J., 2008. Higher Productivity in Importing German Manufacturing Firms: Self-Selection, Learning From Importing, or Both? University of Lüneburg, WP 106.

Wagner, J., 2007. Exports and Productivity: A Survey of The Evidence From Firm Level Data. The World Economy 30, 60-82.

Xu, B., Wang, J., 1999. Capital Goods Trade and R\&D Spillovers in the OECD. Canadian Journal of Economics 32, 1258-1274. 
Let $\bar{x}_{i}$ be the average value over the sample period of some individual characteristic of firm $i$ (say, its productivity). For the control group to be valid, the average value of that individual characteristic should not differ "too much" between the treatment and control group. Two approaches are available to test whether this condition holds. The first is based on the following test statistic:

$$
\operatorname{SDIFF}(x)=\frac{\left(100 / N_{T}\right)\left[\sum_{i \in T}\left(\bar{x}_{i}-w_{i j} \bar{x}_{j}\right)\right]}{\sqrt{\left(\sigma_{x}^{T}+\sigma_{x}^{C}\right) / 2}}
$$

where $\sigma_{x}^{T}$ and $\sigma_{x}^{C}$ are the sample variances of individual characteristic $x$ over the treatment $(T)$ and control $(C)$ groups respectively, $N_{T}$ is the size of the treatment group, and $w_{i j}=w\left(x_{i}, x_{j}\right)$ is the weight given to control firm $j$ in the matching. Although there are no real criteria on the maximum difference which we can accept in an unquestionable way, Rosenbaum and Rubin (1985) suggest that this difference should not exceed 20.

The second test consists of running, for each variable entering the propensity score model, a formal paired t-test between the two groups to satisfy that no significant differences exist.

In the third test we estimate for each variables regression of the form

$$
x=\beta_{0}+\sum_{k=1}^{3} \beta_{k} \hat{p}(\Theta)^{k}+\sum_{k=1}^{3} \gamma_{k} \theta \hat{p}(\Theta)^{k}+\varepsilon
$$

where $\hat{p}(\Theta)$ denotes the estimated propensity score and $\theta$ is a dummy variable equal to 1 if the firm switches import status. As explained by Smith and Todd (2005b), the balancing condition requires the $\gamma$ 's to be jointly insignificant. 
Annex - Tables and figure

Table 1

Descriptive statistics for Spanish firms

\begin{tabular}{|c|c|c|c|c|}
\hline & All & $\begin{array}{c}\text { Non- } \\
\text { importing } \\
\text { firms }\end{array}$ & $\begin{array}{l}\text { Importing } \\
\text { Firms }\end{array}$ & $\begin{array}{c}\text { Switchers } \\
\text { importing } \\
\text { firms }\end{array}$ \\
\hline \# of firms & 2'722 & 766 & 1'100 & 856 \\
\hline (Percent of total) & $(100 \%)$ & $(28 \%)$ & $(40 \%)$ & $(32 \%)$ \\
\hline Output $(Y)$ & $\begin{array}{c}\text { 6'383.38 } \\
(28472.22)^{*}\end{array}$ & $\begin{array}{c}331.72 \\
(1370.18)\end{array}$ & $\begin{array}{l}10 ; 860.06 \\
(36908.07)\end{array}$ & $\begin{array}{c}5 ' 521.95 \\
(26453.37)\end{array}$ \\
\hline Capital $(K)$ & $\begin{array}{c}\text { 3'118.55 } \\
(15791.3)\end{array}$ & $\begin{array}{c}143.2 \\
(581.47)\end{array}$ & $\begin{array}{c}5^{\prime} 432.32 \\
(22070.15)\end{array}$ & $\begin{array}{c}2 ' 580.21 \\
(11996.91)\end{array}$ \\
\hline Labor $(L)$ & $\begin{array}{c}273 \\
(834)\end{array}$ & $\begin{array}{c}31 \\
(60)\end{array}$ & $\begin{array}{c}453 \\
(1118)\end{array}$ & $\begin{array}{c}237 \\
(687)\end{array}$ \\
\hline Intermediates $(M)$ & $\begin{array}{c}3 ' 749.457 \\
(20947.26)\end{array}$ & $\begin{array}{l}165.83 \\
(801.4)\end{array}$ & $\begin{array}{c}6^{\prime} 466.63 \\
(27662.21)\end{array}$ & $\begin{array}{c}3 ’ 164.61 \\
(18887.43)\end{array}$ \\
\hline Markup & $\begin{array}{c}0.223 \\
(0.137)\end{array}$ & $\begin{array}{c}0.208 \\
(0.141)\end{array}$ & $\begin{array}{c}0.230 \\
(0.131)\end{array}$ & $\begin{array}{c}0.225 \\
(0.141)\end{array}$ \\
\hline Capital-labor ratio & $\begin{array}{l}\text { 6'278.124 } \\
\text { (7'013.4) }\end{array}$ & $\begin{array}{l}\text { 3'073.81 } \\
(4 ' 155.97)\end{array}$ & $\begin{array}{l}\text { 8'529.33 } \\
\text { (8'001.36) }\end{array}$ & $\begin{array}{l}5,958.96 \\
(6,464.18)\end{array}$ \\
\hline Export ratio $(X / Y)$ & $\begin{array}{c}0.164 \\
(0.243)\end{array}$ & $\begin{array}{c}0.028 \\
(0.114)\end{array}$ & $\begin{array}{c}0.267 \\
(0.266)\end{array}$ & $\begin{array}{c}0.143 \\
(0.228)\end{array}$ \\
\hline $\begin{array}{l}\text { Export ratio for } \\
\text { exporting firms }\end{array}$ & $\begin{array}{c}0.272 \\
(0.261)\end{array}$ & $\begin{array}{c}0.178 \\
(0.237)\end{array}$ & $\begin{array}{c}0.305 \\
(0.263)\end{array}$ & $\begin{array}{c}0.237 \\
(0.253)\end{array}$ \\
\hline Import ratio & 0.151 & & 0.171 & 0.091 \\
\hline $\begin{array}{c}{[(M+I) * /(M+I)], \text { whole }} \\
\text { sample }\end{array}$ & $(0.223)$ & - & (0.155) & $(0.169)$ \\
\hline $\begin{array}{l}\text { Import ratio, importing } \\
\text { firms only }\end{array}$ & $\begin{array}{l}0.250 \\
(0.240)\end{array}$ & - & $\begin{array}{c}0.297 \\
(0.246)\end{array}$ & $\begin{array}{c}0.159 \\
(0.197)\end{array}$ \\
\hline $\mathrm{R} \& \mathrm{D}$ ratio $[R \& D /(M+I)]$ & $\begin{array}{c}0.015 \\
(0.058)\end{array}$ & $\begin{array}{c}0.003 \\
(0.023)\end{array}$ & $\begin{array}{c}0.025 \\
(0.072)\end{array}$ & $\begin{array}{c}0.013 \\
(0.056)\end{array}$ \\
\hline $\begin{array}{l}\text { Foreign capital share } \\
\qquad\left(K^{*} / K\right)\end{array}$ & $\begin{array}{c}0.187 \\
(0.372)\end{array}$ & $\begin{array}{c}0.009 \\
(0.086)\end{array}$ & $\begin{array}{c}0.346 \\
(0.451)\end{array}$ & $\begin{array}{c}0.131 \\
(0.320)\end{array}$ \\
\hline $\begin{array}{l}\text { Foreign capital share if } \\
\text { foreign capital }>0\end{array}$ & $\begin{array}{c}0.839 \\
(0.273)\end{array}$ & $\begin{array}{c}0.697 \\
(0.289)\end{array}$ & $\begin{array}{c}0.858 \\
(0.263)\end{array}$ & $\begin{array}{c}0.807 \\
(0.295)\end{array}$ \\
\hline Age & $\begin{array}{l}24.12 \\
(22.3)\end{array}$ & $\begin{array}{c}14.5 \\
(13.96)\end{array}$ & $\begin{array}{c}30.22 \\
(24.19)\end{array}$ & $\begin{array}{c}23.84 \\
(22.31)\end{array}$ \\
\hline Skilled-labor share & $\begin{array}{c}0.101 \\
(0.110)\end{array}$ & $\begin{array}{c}0.049 \\
(0.077) \\
\end{array}$ & $\begin{array}{c}0.134 \\
(0.116)\end{array}$ & $\begin{array}{c}0.100 \\
(0.108)\end{array}$ \\
\hline
\end{tabular}

* Standard errors are in parentheses.

Output, capital and intermediate purchases are measured in millions of constant Pesetas. Labor is the number of employees. Markups are calculated as [(sales - avarage costs)/sales] which is an approximation of the Lerner index. Export ratios are relative to firm output. Import and $R \& D$ ratios are relative to the sum total intermediates and total investment by firm $(\mathrm{M}+\mathrm{I}) .(\mathrm{M}+\mathrm{I})^{*}$ are the imported intermediates and investment goods. 
Table 2

Production function parameter estimates, by industry

\begin{tabular}{|c|c|c|c|c|c|c|c|c|c|}
\hline \multicolumn{10}{|c|}{ Dependent variable $: \ln \left(y_{i t}\right)$} \\
\hline Industry & & Variable & Coef. & S.E. & Industry & & Variable & Coef. & S.E. \\
\hline Food \& tobacco & 1 & $\begin{array}{l}l \\
k \\
m \\
N\end{array}$ & $\begin{array}{l}0,250^{* * *} \\
0,322^{* * *} \\
0,513^{* * *} \\
2388\end{array}$ & $\begin{array}{l}(0,024) \\
(0,023) \\
(0,032)\end{array}$ & $\begin{array}{l}\text { Other non- metall. } \\
\text { mineral prod. }\end{array}$ & 8 & $\begin{array}{l}l \\
k \\
m \\
N\end{array}$ & $\begin{array}{l}0,605^{* * *} \\
0,267^{* * *} \\
0,317^{* * *} \\
1140\end{array}$ & $\begin{array}{l}(0,043) \\
(0,035) \\
(0,041)\end{array}$ \\
\hline $\begin{array}{l}\text { Textiles \& textile } \\
\text { prod. }\end{array}$ & 2 & $\begin{array}{l}l \\
k \\
m \\
N\end{array}$ & $\begin{array}{l}0,426^{* * *} \\
0,220^{* * *} \\
0,417^{* * *} \\
1444\end{array}$ & $\begin{array}{l}(0,033) \\
(0,029) \\
(0,024)\end{array}$ & $\begin{array}{l}\text { Basic metals \& fab. } \\
\text { metal prod. }\end{array}$ & 9 & $\begin{array}{l}l \\
k \\
m \\
N\end{array}$ & $\begin{array}{l}0,409^{* * *} \\
0,205^{* * *} \\
0,470^{* * *} \\
2030\end{array}$ & $\begin{array}{l}(0,025) \\
(0,018) \\
(0,025)\end{array}$ \\
\hline $\begin{array}{l}\text { Leather \& leather } \\
\text { prod. }\end{array}$ & 3 & $\begin{array}{l}l \\
k \\
m \\
N\end{array}$ & $\begin{array}{l}0,124^{* * *} \\
0,152^{* * *} \\
0,581^{* * *} \\
382\end{array}$ & $\begin{array}{l}(0,036) \\
(0,020) \\
(0,029)\end{array}$ & $\begin{array}{l}\text { Machinary \& } \\
\text { equipment }\end{array}$ & 10 & $\begin{array}{l}l \\
k \\
m \\
N\end{array}$ & $\begin{array}{l}0,398^{* * *} \\
0,266^{* * *} \\
0,429^{* * *} \\
1241\end{array}$ & $\begin{array}{l}(0,039) \\
(0,034) \\
(0,036)\end{array}$ \\
\hline Wood and Paper & 4 & $\begin{array}{l}l \\
k \\
m \\
N\end{array}$ & $\begin{array}{l}0,282^{* * *} \\
0,176^{* * *} \\
0,583^{* * *} \\
857\end{array}$ & $\begin{array}{l}(0,028) \\
(0,017) \\
(0,027)\end{array}$ & $\begin{array}{l}\text { Office equip. \& } \\
\text { precision inst. }\end{array}$ & 11 & $\begin{array}{l}l \\
k \\
m \\
N\end{array}$ & $\begin{array}{l}0,236^{* * *} \\
0,257^{* * *} \\
0,567^{* * *} \\
283\end{array}$ & $\begin{array}{l}(0,050) \\
(0,046) \\
(0,034)\end{array}$ \\
\hline Printing prod. & 5 & $\begin{array}{l}l \\
k \\
m \\
N\end{array}$ & $\begin{array}{l}0,410^{* * * *} \\
0,274^{* * *} \\
0,372^{* * *} \\
868\end{array}$ & $\begin{array}{l}(0,048) \\
(0,038) \\
(0,030)\end{array}$ & $\begin{array}{l}\text { Electric. \& optical } \\
\text { equip. }\end{array}$ & 12 & $\begin{array}{l}l \\
k \\
m \\
N\end{array}$ & $\begin{array}{l}0,324^{* * *} \\
0,174^{* * *} \\
0,536^{* * *} \\
1234\end{array}$ & $\begin{array}{l}(0,025) \\
(0,014) \\
(0,022)\end{array}$ \\
\hline Chemical prod. & 6 & $\begin{array}{l}l \\
k \\
m \\
N\end{array}$ & $\begin{array}{l}0,465^{* * *} \\
0,167^{* * *} \\
0,437^{* * *} \\
1236\end{array}$ & $\begin{array}{l}(0,072) \\
(0,013) \\
(0,064)\end{array}$ & Transport equip. & 13 & $\begin{array}{l}l \\
k \\
m \\
N\end{array}$ & $\begin{array}{l}0,342^{* * *} \\
0,137^{* * *} \\
0,571^{* * *} \\
1181\end{array}$ & $\begin{array}{l}(0,032) \\
(0,016) \\
(0,023)\end{array}$ \\
\hline $\begin{array}{l}\text { Rubber \& plastic } \\
\text { prod. }\end{array}$ & 7 & $\begin{array}{l}l \\
k \\
m \\
N\end{array}$ & $\begin{array}{l}0,425^{* * *} \\
0,232^{* * *} \\
0,414^{* * *} \\
949\end{array}$ & $\begin{array}{l}(0,069) \\
(0,018) \\
(0,081)\end{array}$ & Other manuf. Prod. & 14 & $\begin{array}{l}l \\
k \\
m \\
N\end{array}$ & $\begin{array}{l}0,263^{* * *} \\
0,255^{* * *} \\
0,481^{* * *} \\
1070\end{array}$ & $\begin{array}{l}(0,029) \\
(0,008) \\
(0,043)\end{array}$ \\
\hline
\end{tabular}

Source : autors' calculation. Standard errors are in parenthesis $*$ significant at $10 \%, * *$ at $5 \%$; $* * *$ at $1 \%$. 
Table 3

Balancing score tests, TFP

\begin{tabular}{cccc}
\hline \hline Year & $\begin{array}{c}\text { Average } \\
\text { standardized } \\
\text { difference (\%) }\end{array}$ & $\begin{array}{c}\text { pegression- } \\
\text { based test }\end{array}$ & t-test \\
\hline 1993 & 9,11 & 0.999 & 0.902 \\
1994 & 7,87 & 0.431 & 0.922 \\
1995 & 8,78 & 0.426 & 0.714 \\
1996 & 11,04 & 0.920 & 0.711 \\
1997 & 9,96 & 0.518 & 0.558 \\
1998 & 8,04 & 0.759 & 0.959 \\
1999 & 7,11 & 0.943 & 0.842 \\
2000 & 14,88 & 0.721 & 0.579 \\
2001 & 14,09 & 0.278 & 0.222 \\
2002 & 10,89 & 0.620 & 0.483 \\
\hline
\end{tabular}

Notes: Standardized differences are calculated for each of the matching variables using the equation (A1) in annex. Regression-based tests are conducted for all explanatory variables included in the probit specification. We test for the joint significance of the $\gamma$ coefficients. A pvalue greater than the specified significance level (say $5 \%$ ) is evidence in favour of balancing. Formal paired t-tests are conducted for all explanatory variables included in the probit regression. 
Table 4

Effect of import status on TFP

\begin{tabular}{|c|c|c|c|c|c|c|}
\hline \multicolumn{7}{|c|}{ Dependent variable: $\ln \left(\mathrm{TFP}_{\mathrm{it}}\right)$} \\
\hline & \multicolumn{3}{|c|}{ OLS } & \multicolumn{3}{|c|}{ Outlier robust regression } \\
\hline & $(1)$ & $(2)$ & $(3)$ & $(4)$ & $(5)$ & $(6)$ \\
\hline \multicolumn{7}{|l|}{ No interaction: } \\
\hline Entry year & $\begin{array}{l}0.024 \\
(0.033)\end{array}$ & & $\begin{array}{l}-0.024 \\
(0.037)\end{array}$ & $\begin{array}{l}0.013 \\
(0.034)\end{array}$ & & $\begin{array}{l}-0.037 \\
(0.040)\end{array}$ \\
\hline Entry year +1 & $\begin{array}{l}0.025 \\
(0.036)\end{array}$ & & $\begin{array}{l}-0.031 \\
(0.040)\end{array}$ & $\begin{array}{l}0.014 \\
(0.037)\end{array}$ & & $\begin{array}{l}-0.040 \\
(0.042)\end{array}$ \\
\hline Entry year +2 & $\begin{array}{l}0.033 \\
(0.039)\end{array}$ & & $\begin{array}{l}-0.007 \\
(0.044)\end{array}$ & $\begin{array}{l}0.024 \\
(0.040)\end{array}$ & & $\begin{array}{l}-0.014 \\
(0.046)\end{array}$ \\
\hline \multicolumn{7}{|c|}{ Interaction variable : } \\
\hline \multicolumn{7}{|c|}{ Single switchers } \\
\hline Entry year & & $\begin{array}{l}0.104^{* *} \\
(0.051)\end{array}$ & & & $\begin{array}{l}0.086^{*} \\
(0.052)\end{array}$ & \\
\hline Entry year + 1 & & $\begin{array}{l}0.155^{* * *} \\
(0.051)\end{array}$ & & & $\begin{array}{l}0.122^{* *} \\
(0.058)\end{array}$ & \\
\hline Entry year +2 & & $\begin{array}{l}0.167^{* * *} \\
(0.056)\end{array}$ & & & $\begin{array}{l}0.131^{* *} \\
(0.064)\end{array}$ & \\
\hline \multicolumn{7}{|c|}{ Multiple switchers } \\
\hline Entry year & & $\begin{array}{l}-0.030 \\
(0.042)\end{array}$ & & & $\begin{array}{l}-0.036 \\
(0.044)\end{array}$ & \\
\hline Entry year + 1 & & $\begin{array}{l}-0.061 \\
(0.046)\end{array}$ & & & $\begin{array}{l}-0.064 \\
(0.047)\end{array}$ & \\
\hline Entry year +2 & & $\begin{array}{l}-0.045 \\
(0.050)\end{array}$ & & & $\begin{array}{l}-0.043 \\
(0.051)\end{array}$ & \\
\hline \multicolumn{7}{|l|}{ Skills } \\
\hline Entry year & & & $\begin{array}{l}0.905^{* * *} \\
(0.275)\end{array}$ & & & $\begin{array}{l}0.887^{* *} \\
(0.376)\end{array}$ \\
\hline Entry year +1 & & & $\begin{array}{l}1.064^{* * *} \\
(0.263)\end{array}$ & & & $\begin{array}{l}0.941^{* *} \\
(0.388)\end{array}$ \\
\hline Entry year +2 & & & $\begin{array}{l}0.798^{* * *} \\
(0.274)\end{array}$ & & & $\begin{array}{l}0.682^{*} \\
(0.401)\end{array}$ \\
\hline Constant & $\begin{array}{l}2,865^{* * *} \\
(0,111)\end{array}$ & $\begin{array}{l}2.967^{* * *} \\
(0.108)\end{array}$ & $\begin{array}{l}2.866^{* * *} \\
(0.111)\end{array}$ & $\begin{array}{l}2.772^{* * *} \\
(0.088)\end{array}$ & $\begin{array}{l}3.032^{* * *} \\
(0.093)\end{array}$ & $\begin{array}{l}2.773^{* * *} \\
(0.088) \\
\end{array}$ \\
\hline $\begin{array}{l}\text { Localisation } \\
\text { dummies }\end{array}$ & yes & yes & yes & yes & yes & yes \\
\hline Year dummies & yes & yes & yes & yes & yes & yes \\
\hline Observations & 5503 & 5503 & 5503 & 5503 & 5503 & 5503 \\
\hline $\mathrm{R}^{2}$ & 0.09 & 0.10 & 0.09 & 0.10 & 0.10 & 0.09 \\
\hline
\end{tabular}


Table 5

Direct approach production function parameter estimates, by industry

\begin{tabular}{|c|c|c|c|c|c|c|c|c|c|}
\hline \multicolumn{10}{|c|}{ Dependent variable $: \ln \left(y_{i t}\right)$} \\
\hline Industry & & Variable & Coef. & S.E. & Industry & & Variable & Coef. & S.E. \\
\hline \multirow{5}{*}{ Food \& tobacco } & \multirow{5}{*}{1} & $l$ & $0,250^{* * * *}$ & $(0,023)$ & \multirow{5}{*}{$\begin{array}{l}\text { Other non- metall. } \\
\text { mineral prod. }\end{array}$} & \multirow{5}{*}{8} & $l$ & $0,586^{* * *}$ & $(0,052)$ \\
\hline & & $k$ & $0,346^{* * *}$ & $(0,028)$ & & & $k$ & $0,301^{* * *}$ & $(0,042)$ \\
\hline & & $m$ & $0,524^{* * * *}$ & $(0,027)$ & & & $m$ & $0,314^{* * *}$ & $(0,056)$ \\
\hline & & Mshare $_{t-1}$ & $0,116^{*}$ & $(0,060)$ & & & Mshare $_{t-1}$ & 0,011 & $(0,095)$ \\
\hline & & $\mathrm{N}$ & 2039 & & & & $\mathrm{~N}$ & 1731 & \\
\hline \multirow{5}{*}{$\begin{array}{l}\text { Textiles \& textile } \\
\text { prod. }\end{array}$} & \multirow{5}{*}{2} & $l$ & $0,408^{* * * *}$ & $(0,041)$ & \multirow{5}{*}{$\begin{array}{l}\text { Basic metals \& fab. } \\
\text { metal prod. }\end{array}$} & \multirow{5}{*}{9} & $l$ & $0,380^{* * * *}$ & $(0,026)$ \\
\hline & & $k$ & $0,178^{* * *}$ & $(0,016)$ & & & $k$ & $0,193^{* * *}$ & $(0,020)$ \\
\hline & & $m$ & $0,434^{* * * *}$ & $(0,029)$ & & & $m$ & $0,500^{* * * *}$ & $(0,018)$ \\
\hline & & Mshare $_{t-1}$ & $0,201^{* * *}$ & $(0,060)$ & & & Mshare $_{t-1}$ & $0,156^{* * *}$ & $(0,046)$ \\
\hline & & $\mathrm{N}$ & 1229 & & & & $\mathrm{~N}$ & 1062 & \\
\hline \multirow{5}{*}{$\begin{array}{l}\text { Leather \& leather } \\
\text { prod. }\end{array}$} & \multirow{5}{*}{3} & $l$ & $0,103^{* *}$ & $(0,041)$ & \multirow{5}{*}{$\begin{array}{l}\text { Machinary \& } \\
\text { equipment }\end{array}$} & \multirow{5}{*}{10} & $l$ & $0,410^{* * *}$ & $(0,045)$ \\
\hline & & $k$ & $0,180^{* * * *}$ & $(0,018)$ & & & $k$ & $0,236^{* * * *}$ & $(0,034)$ \\
\hline & & $m$ & $0,612^{* * *}$ & $(0,036)$ & & & $m$ & $0,443^{* * *}$ & $(0,045)$ \\
\hline & & Mshare $_{t-1}$ & $-0,039$ & $(0,061)$ & & & Mshare $_{t-1}$ & $0,281^{* * *}$ & $(0,069)$ \\
\hline & & $\mathrm{N}$ & 320 & & & & $\mathrm{~N}$ & 1153 & \\
\hline \multirow{5}{*}{ Wood and Paper } & \multirow{5}{*}{4} & $l$ & $0,277^{* * *}$ & $(0,031)$ & \multirow{5}{*}{$\begin{array}{l}\text { Office equip. \& } \\
\text { precision inst. }\end{array}$} & \multirow{5}{*}{11} & $l$ & $0,160^{* *}$ & $(0,081)$ \\
\hline & & $k$ & $0,169^{* * * *}$ & $(0,016)$ & & & $k$ & $0,394^{* * *}$ & $(0,071)$ \\
\hline & & $m$ & $0,580^{* * * *}$ & $(0,026)$ & & & $m$ & $0,581^{* * *}$ & $(0,052)$ \\
\hline & & Mshare $_{t-1}$ & 0,027 & $(0,047)$ & & & Mshare $_{t-1}$ & $0,201^{* *}$ & $(0,086)$ \\
\hline & & $\mathrm{N}$ & 709 & & & & $\mathrm{~N}$ & 227 & \\
\hline \multirow{5}{*}{ Printing prod. } & \multirow{5}{*}{5} & $l$ & $0,399^{* * *}$ & $(0,062)$ & \multirow{5}{*}{$\begin{array}{l}\text { Electric. \& optical } \\
\text { equip. }\end{array}$} & \multirow{5}{*}{12} & $l$ & $0,306^{* * *}$ & $(0,029)$ \\
\hline & & $k$ & $0,168^{* * * *}$ & $(0,015)$ & & & $k$ & $0,157^{* * * *}$ & $(0,018)$ \\
\hline & & $m$ & $0,356^{* * *}$ & $(0,034)$ & & & $m$ & $0,570^{* * *}$ & $(0,027)$ \\
\hline & & Mshare $_{t-1}$ & $0,426^{* * *}$ & $(0,071)$ & & & Mshare $_{t-1}$ & $0,107^{* * *}$ & $(0,044)$ \\
\hline & & $\mathrm{N}$ & 1061 & & & & $\mathrm{~N}$ & 1053 & \\
\hline \multirow{5}{*}{ Chemical prod. } & \multirow{5}{*}{6} & $l$ & $0,476^{* * *}$ & $(0,087)$ & \multirow{5}{*}{ Transport equip. } & \multirow{5}{*}{13} & $l$ & $0,353^{* * *}$ & $(0,036)$ \\
\hline & & $k$ & $0,118^{* * *}$ & $(0,007)$ & & & $k$ & $0,142^{* * *}$ & $(0,015)$ \\
\hline & & $m$ & $0,442^{* * *}$ & $(0,081)$ & & & $m$ & $0,553^{* * *}$ & $(0,028)$ \\
\hline & & Mshare $_{t-1}$ & $0,121^{* * *}$ & $(0,039)$ & & & Mshare $_{t-1}$ & $0,173^{* * *}$ & $(0,042)$ \\
\hline & & $\mathrm{N}$ & 804 & & & & $\mathrm{~N}$ & 1010 & \\
\hline \multirow{5}{*}{$\begin{array}{l}\text { Rubber \& plastic } \\
\text { prod. }\end{array}$} & & $l$ & $0,396^{* * *}$ & $(0,094)$ & & & $l$ & $0,260^{* * *}$ & $(0,031)$ \\
\hline & & $k$ & $0,278^{* * * *}$ & $(0,023)$ & & & $k$ & $0,254^{* * *}$ & $(0,008)$ \\
\hline & 7 & $m$ & $0,408^{* * *}$ & $(0,123)$ & Other manuf. Prod. & 14 & $m$ & $0,470^{* * *}$ & $(0,033)$ \\
\hline & & Mshare $_{t-1}$ & 0,035 & $(0,061)$ & & & Mshare $_{t-1}$ & $0,089^{* *}$ & $(0,045)$ \\
\hline & & $\mathrm{N}$ & 985 & & & & $\mathrm{~N}$ & 921 & \\
\hline
\end{tabular}

Source : autors' calculation. Standard errors are in parenthesis ${ }^{*}$ significant at $10 \%,{ }^{* *}$ at $5 \% ;{ }^{* * *}$ at $1 \%$. 
Table 1

Direct approach production function parameter estimates, by group

\begin{tabular}{|c|c|c|c|c|c|c|c|c|c|c|}
\hline & \multirow{3}{*}{$\begin{array}{c}\text { No interaction } \\
\text { (1) }\end{array}$} & \multicolumn{9}{|c|}{ Interaction } \\
\hline & & $\begin{array}{c}\text { Skill intensity } \\
\text { (2) }\end{array}$ & $\begin{array}{c}\text { R\&D Intensity } \\
\text { (3) }\end{array}$ & $\begin{array}{l}\text { Foreign capital } \\
\text { (4) }\end{array}$ & \multicolumn{2}{|c|}{$\begin{array}{c}\text { Export intensity } \\
\text { (5) }\end{array}$} & \multicolumn{2}{|c|}{$\begin{array}{c}\text { Profit growth } \\
\text { (6) }\end{array}$} & \multicolumn{2}{|c|}{$\begin{array}{c}\text { Market share } \\
\text { (7) }\end{array}$} \\
\hline & & High Low & High Low & High Low & High & Low & High & Low & High & Low \\
\hline$l$ & $\begin{array}{l}0,363^{* * *} \\
(0,011)\end{array}$ & $\begin{array}{c}0,364^{* * *} \\
(0,013)\end{array}$ & $\begin{array}{c}0,366^{* * *} \\
(0,013)\end{array}$ & $\begin{array}{c}0,365^{* * *} \\
(0,013)\end{array}$ & \multicolumn{2}{|c|}{$\begin{array}{c}0,364^{* * *} \\
(0,013)\end{array}$} & \multicolumn{2}{|c|}{$\begin{array}{c}0,364^{* * *} \\
(0,013)\end{array}$} & \multicolumn{2}{|c|}{$\begin{array}{c}0,365^{* * *} \\
(0,013)\end{array}$} \\
\hline$k$ & $\begin{array}{l}0,240^{* * *} \\
(0,007)\end{array}$ & $\begin{array}{l}0,223^{* * *} \\
(0,007)\end{array}$ & $\begin{array}{l}0,233^{* * *} \\
(0,008)\end{array}$ & $\begin{array}{c}0,235^{* * *} \\
(0,008)\end{array}$ & $\begin{array}{l}0,2 \\
(0,\end{array}$ & $4^{* * *}$ & \multicolumn{2}{|c|}{$\begin{array}{c}0,232^{* * *} \\
(0,008)\end{array}$} & \multicolumn{2}{|c|}{$\begin{array}{c}0,232^{* * *} \\
(0,008)\end{array}$} \\
\hline$m$ & $\begin{array}{c}0,479^{* * *} \\
(0,012)\end{array}$ & $\begin{array}{c}0,480^{* * *} \\
(0,015)\end{array}$ & $\begin{array}{c}0,482^{* * *} \\
(0,015)\end{array}$ & $\begin{array}{c}0,481^{* * *} \\
(0,015)\end{array}$ & $\begin{array}{r}0,4 \\
\text { (o }\end{array}$ & $\begin{array}{l}31^{* * *} \\
015)\end{array}$ & \multicolumn{2}{|c|}{$\begin{array}{c}0,482^{* * *} \\
(0,015)\end{array}$} & \multicolumn{2}{|c|}{$\begin{array}{c}0,482^{* * *} \\
(0,015)\end{array}$} \\
\hline$\mu^{*}$ & $\begin{array}{l}0,194^{* * *} \\
(0,015)\end{array}$ & $\begin{array}{ll}0,415^{* * *} & 0,026 \\
(0,024) & (0,018)\end{array}$ & $\begin{array}{ll}0,203^{* * *} & 0,195^{* * *} \\
(0,018) & (0,022)\end{array}$ & $\begin{array}{ll}0,229^{* * *} & 0,097^{* * *} \\
(0,018) & (0,025)\end{array}$ & $\begin{array}{l}0,122^{* * *} \\
(0,018)\end{array}$ & $\begin{array}{l}0,331^{* * *} \\
(0,023)\end{array}$ & $\begin{array}{l}0,250^{* * *} \\
(0,025)\end{array}$ & $\begin{array}{l}0,179^{* * *} \\
(0,017)\end{array}$ & $\begin{array}{l}0,219^{* * *} \\
(0,017)\end{array}$ & $\begin{array}{l}0,145^{* * *} \\
(0,025)\end{array}$ \\
\hline $\begin{array}{l}\text { Industry } \\
\text { dummies }\end{array}$ & yes & yes & yes & yes & & es & & es & & es \\
\hline Obs. & 16303 & 13765 & 14073 & 14073 & & 073 & 14 & 47 & & 97 \\
\hline
\end{tabular}


Figure 1

Average TFP by import status

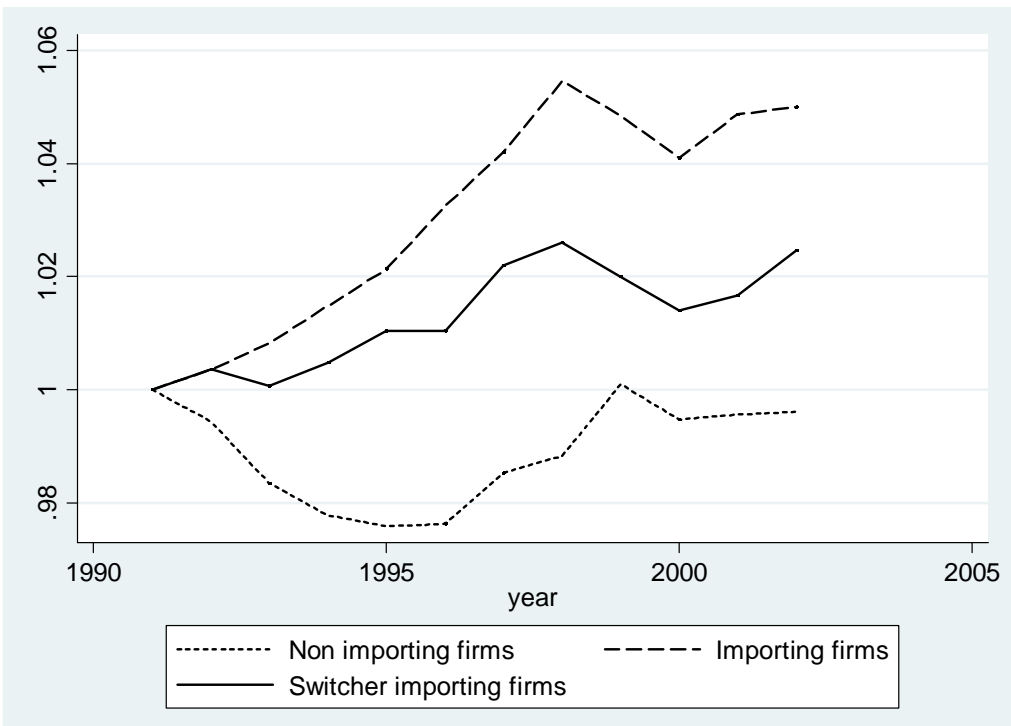

